\title{
STUDIES IN ORGANISATIONAL SEMIOTICS: AN INTRODUCTION
}

\author{
Rodney J. Clarke \\ Department of Information Systems, \\ University of Wollongong, AUSTRALIA \\ Phone: +6142213752 Fax: +6142214474 \\ rodney_clarke@uow.edu.au
}

\section{ORIENTATION TO SEMIOTICS}

The broad application of semiotic approaches to organisations has been considered by a number of information systems academics to be a necessary advance in information systems theory (see for examples Land 1985, Rzevski 1985, and Tully 1985). Along with psychology and sociology, semiotics is considered to be a foundation discipline for information systems within the IFIP WG 8.1 FRISCO Framework (Falkenberg, et al eds/2000). Semiotics examines the processes of production and consumption of meanings in organisations, institutions and society, and their underlying mechanisms by means of what Pap $(1991,47)$ refers to as a "...systematic analysis of patterns of interpretive behaviour". Although often unacknowledged, meaning is central to any definition of an information system. While the concept of meaning and meaning making is difficult to define, semiotic theory can assist by emphasising the distinctions between 'information', 'meaning', 'sense' and 'reference' for example (see Nöth 1990, 92-102). Eco $(1976,8)$, provides a broad definition of semiotics as the study of "....all cultural processes as processes of communication". Cultural processes are interpreted to include organisational contexts and processes thereby providing a link between systems and organisations.

Most applied semiotic studies start by identifying or defining one or more models of the sign as the basic unit of analysis. Signs are usually glossed as 'something that stands for something else in some capacity or another'. Depending on the model of the sign, mention may be made to an entity for whom the 'stands for' relationship applies. For a discipline often defined as the 'study of signs', there are a plethora of distinct sign models from which to choose. The reader is directed to Winfried Nöth's Handbook of Semiotics for a detailed description of different sign typologies, sign models and disciplinary history (Nöth 1990, 79-91). The period of modem semiotics starts at the beginning of the $20^{\text {th }}$ Century with the emergence of two independent traditions. The work of Ferdinand de Saussure represents one of these traditions. Considered to be the founder of modern linguistics, he is also a pivotal figure in semiotics by distinguishing the former from the later in Cours de linguistique générale (1916)- a volume assembled from lecture notes edited by colleagues and published three years after his death (currently available as Bally, Sechehaye and Riedlinger eds/ 1993). The other tradition is represented by the work of Charles Sanders Peirce, a founder of symbolic logic as well as an expert in philosophy, mathematics, and many other fields. Peirce developed a pansemiotic view so all-inclusive and elaborate that the definitive, chronological collection of his work called the Peirce Edition Project remains unfinished, only six of an estimated twenty volumes of have been published to date (see for example Houser et al eds/ 1999). Other semiotic traditions exist. There are semiotic forms of linguistics - referred to here as semio-linguistics - which adopt a semiotic theorisation of text rather than using an explicit sign model during analysis. Examples include text semiotics, systemic functional linguistics (Halliday 1978, 1985; Martin 1992) and systemic semiotics (Fawcett 1986). There is also at least one influential form of semio-linguistics that does uses an explicit sign model (Hjelmslev 1943/1963), while Social Semiotics (Kress 1985; Hodge and Kress 1988) develops concepts of discourse, text and social subjectivity based on the 'social sign' of Bakhtin (see Todorov 1984).

Despite the obvious applicability to information systems of a discipline that concerns itself with the study of 'patterns of interpretive behaviour', there have been impediments to more vigorous interchange between semiotics and informatics. There are several contributory reasons for this situation. A major contributory reason is that Western semiotics likes to trace its lineage back to the Stoics (approximately $300 \mathrm{BC}$ to $200 \mathrm{BC}$ ) and the Epicureans ( $300 \mathrm{BC}$ to 0 ) through to the Enlightenment and onto the $19^{\text {th }}$ and $20^{\text {th }}$ Centuries. Faced with this daunting history, and a diversity of researchers, theories, and terminology to rival the most entrenched of moderm disciplines, it is not surprising that a casual 'dip' into the literature might prove unproductive. Moreover, as semiotics is centrally involved with understanding communication, it becomes obvious that many commonsense notions of what constitutes communication would need to be reconsidered. As a consequence, semiotics unusually needs to employ meta-theory of one form or another, which leave it open to charges of obscurantism and elitism (Sless 1986, 2). However, it is unreasonable to assume that the constructs used to explain and examine such complex and taken-for granted cultural phenomena must necessarily be simple. Another major contributory reason is the difficulty of locating semiotics within any single discipline- semiotics is inherently trans-disciplinary. Broad application domains have included, but are not limited to, the cultural constitution of subjectivity, criticism and knowledge, communication and perception. A sample of subjects using semiotic theory of one form or another would include cultural and literary studies, film criticism, feminism, political science, legal studies, town planning and architecture, anthropology, biology and genetics. Moreover, there is considerable debate about what constitutes the core criteria that defines semiotics (Pap 1991). 


\section{SEMIOTICS APPLIED TO INFORMATIC DOMAINS}

Semiotics has always been implicit within informatic domains including computing science and information systems (Marcus 1996, 1999). The realisation of the semiotic nature of information systems in organisational contexts has been apparent in the earliest work in semiotics applied to the informatic domains. This is particularly evident in Europe and Scandinavia, where recognition of the need to create organisationally appropriate information systems has helped to maintain an interest in applying semiotics to informatic domains in general. While specific schools may have flourished for a time, most schools have failed to reach critical mass and have been subsumed within traditional and accepted information systems theories and practices. Some specific selections of semiotic theory have been utilised within informatic domains. The preeminent Swedish methodologist Börje Langefors (1966) was an example of one of the earliest information systems academics, circa 1967, who developed an interest in semiotics (Nilsson 1995). He proposed the research project that developed into the ISAC methodology (Dahlbom ed/ 1993, 1995) which had as its definition of elementary information the triadic sign developed by Pierce (see Nöth 1990, 39-47 for a readable account of Pierce's semiotics). Fiol (1989) provides a relatively early and excellent example of a semiotic analysis of organisational boundaries.

Despite the apparent applicability of general semiotics within information systems - shown by the examples of limited exchange between them - there was a relatively sparse and episodic utilisation of general semiotic theory within the information systems and organisations domains. However, since the mid-1990s there has been a broad application of semiotic principles across many application areas. These include but are not limited to Human Computer Interaction (Merkle 1997), ergonomics (Köstler 1999), text analysis and computational text semiotics (see for example, Rieger 1981), hypersystems and hypermedia (Andersen 1990, Clarke 2001, Fendt 1999), agent-based systems and associated methodologies (Schmidt 1999, Chong and Liu 2001), organisational analysis (Stamper 2001), knowledge management (van Heusden and Jorna 1999), and systems evolution (Clarke 1996, 2000). There has also been an explosion of activity both in the number of received terms in use to describe and label research in the area of semiotics and informatics, and the number of workshops and conferences that have put these ideas into circulation. For example, in 1999 there were four international workshops and conferences in the field of semio-informatics while prior to 1995 there were none, see Table 1.

\section{RECEIVED TERMS AND EMERGING DEFINITIONS}

In February 1995, approximately forty researchers, mostly from Europe but also from Scandinavia and Australasia, attended the First International Conference and Workshop on Organisational Semiotics at Twente University in the Netherlands. The term Organisational Semiotics was coined by its chair Ronald Stamper, to refer to the use of any semiotic approach in the study of organisations. The MEASUR Research Group (Method for Eliciting, Analysing and Specifying User Requirements) that Ronald Stamper initiated at the London School of Economics in the United Kingdom, and continued at Twente University in the Netherlands, had since its formation consistently developed and advocated semiotic thinking in informatic domains (Stamper 1973; Kolkman 1993; Liu 1993, 2000). A principle interest at the conference, also evident at a Semiotics and Informatics Dagstuhl Seminar (Andersen, Nadin and Nake 1996) was the application of semiotics to the information systems discipline, referred to as Semio-informatics, a term coined and used independently by the author (Clarke 1995) and Mihai Nadin (1998). Related to this is the intersection of linguistics and informatics domains, which has been referred to as work language studies (Holmqvist and Andersen 1987). Although there are a number of methodological and substantive intersections between then, it is important to theoretically distinguish organisational semiotic work that utilises semiotic models of language

Peter Bøgh Andersen (1990) has coined the term computer semiotics to refer to the application of semiotic principles to computing in its most general sense. The kinds of activities included within the gamut of computer semiotics include amongst other things, program development, interface design, systems description, systems development, work analysis, organisational analysis, and technological assessment (Andersen 1990, 18). However, within Australia and North America there exists a strong institutional demarcation between computer science, information systems and communication technology, and these distinctions raise some problems in appropriately classifying studies. The use of the term 'computer' in computer semiotics is probably a consequence of the broader meaning of the term 'computer science' within Scandinavia, which has propelled Andersen's work and that of his colleagues involved in the System Development environments and Profession Oriented Languages (SYDPOL) group (Andersen and Bratteteig eds/ 1989). This group spanned many interests ranging from the consideration of computers as symbolic and semiotic machines, and the linguistic status of programming languages, to a consideration of work and professionally oriented language in organisations 
(Andersen and Holmqvist 1988). The work of Nadin (1998) dating from 1977 and Döben-Henisch (1998) also use the concept of the computer as a semiotic machine, itself a term which has a history extending back to its coinage by Pierce. The field of computer semiotics and semio-informatics are considered here to be synonyms for the intersection of semiotics and information technology is general, and therefore a part of the broader program of organisational semiotics. Semiotic engineering has also been a term used by de Souza (1998) since 1995 to designate a form of analysis and design which spans the interests of semio-informatics and computer semiotics.

The University of Technology, Dresden recently hosted the $9^{\text {th }}$ International Congress of the German Society for Semiotics Studies (DGS), followed immediately by $7^{\text {th }}$ International Congress of the International Association for Semiotic Studies (IASS/AIS), October 3-6, 1999. The former conference had as its general theme 'Machines and History', where 'machine' was used in two senses referring to a general cultural concept, and also to the physical or conceptual devices describable within a broadly semiotic framework. The latter conference had as its general theme 'Sign Processes in Complex Systems' where 'complex system' was interpreted in a broad interdisciplinary sense. This interest from the mainstream semiotic community is due in part to the novel cases that are provided from Information Systems and Computing Science for testing and further elaborating traditional semiotic theory and developing new semiotic theories in an area now referred to as Computational Semiotics. A conference with this theme was organised in 1997 by Claude Vogel, Suzanne Bertrand-Gastaldy, and Jean-Claude Heudin at the Pôle Universitaire Leonard de Vinci in Paris, France (Vogel et al 1997). The 1999 DGS and IASS/AIS represented an opportunity to hold the first Computational Semiotics session in a mainstream semiotic conference. The session was entitled Computational Semiotic Systems: Theories and Applications and was chaired by Gerd Döben-Henisch, in response to discussions between Prof. Burghard Rieger, Alexander Mehler, Ricardo Gudwin, Gerd Döben-Henisch, Lauwrence Erasmus, and the author held at ISAS'98 with the aim of establishing a semiotic theory of computation. While one part of this community has aims similar to computer semiotics, other parts of this community aim to construct autonomous systems with semiotic processing that will provide them with abilities like intelligent behavior, perception, value judgement and behaviour generation (Gudwin and Gomide 1997; Gudwin 1999).

\section{WORK IN THIS ISSUE}

The title of this theme has been chosen to introduce the new 'Studies in Organisational Semiotics' books being published within the Information and Organisation Design Series by Kluwer Academic Press. Several of the theme's editors have contributed to this issue. The first volume is entitled "Information, Organisation, and Technology" and is already available (Liu et al 2001). A second volume provisionally entitled "Coordination and Communication Using Signs" will be in press by the time you read this. This issue is timely given the recent institutional debates concerning the centrality of semiotics within informatic domains. In 1995, Ronald Stamper was successful in arguing the case for semiotics to be considered, along with psychology and sociology, as a foundation discipline for information systems within the IFIP WG 8.1 FRISCO framework. In particular, the efforts of Ronald Stamper and Kecheng Liu have led to the forthcoming IFIP WG8.1 Working Conference entitled "Organisational Semiotics: Evolving a science of Information Systems" which will soon be held between during $23^{\text {rd }}$ to the $25^{\text {th }}$ July, Montreal, Canada.

In order to review the papers for this special issue we were ably assisted by a committee consisting of the following scholars including: Maria Cecilia Calani Baranauskas Institute of Computing, Universidade Estadual de Campinas (UNICAMP), Brazil; Joseph Davis Basser Department of Computer Science, The University of Sydney, Australia; Ermest A. Edmonds Department of Computer Science, Loughborough University, United Kingdom; Henk W. M. Gazendam Faculty of Management and Organization, University of Groningen, The Netherlands; Aditya Ghose Department of Information System, University of Wollongong, Australia; Goran Goldkuhl Linkoping University (CMTO), Sweden; Remigijus Gustas Department of Information Systems, Karlstad University, Sweden; Martin Kolkman Department of Management, Ball State University, USA and Pricewaterhouse/Coopers LLP, USA; Kecheng Liu School of Computing, Staffordshire University, United Kingdom; and Laurent Perrussel IRIT/CERISS, University of Toulouse 1, France. The authors and I am indebted to the reviewers for their engagement with this work.

The authors have been invited to participate in this issue based on their commitment to the field of Organisational Semiotics. They hail from Australia, Brazil, Canada, Denmark, and Germany- a demonstration of the extent to which this is an international community. Specific topics have been chosen to exemplify the range and diversity of the Organisational Semiotics and to highlight its utility for information systems, organisational studies and related fields. The papers focus on diverse application domains including the analysis of maritime workpractices (Peter Bøgh Andersen), scenario-based design of a workflow system (Clarisse Sieckenius de Souza; Cecilia Kremer Vieira da Cunha, Raquel Oliveira Prates and Simone Diniz Junqueira Barbosa), development of innovative approaches to text mining (Alexander Mehler), the analysis of a small operational 
level administrative system (Rodney J. Clarke), and a study into the discourses surrounding concerning knowledge management (Rob Shields and Edwina Taborsky). While exhibiting a variety of theoretical approaches and substantive interests, these papers share one feature. All recognise the centrality of human communication as a way of understanding meaning making in institutional and organisational contexts, whether this be signs in design scenarios, communication and work language, text mining and hypertext generation, systems features and workpractices, and the contestable definitions of information and knowledge. 
Table 1: Recent Organisational Semiotics and Computational Semiotics workshops and conferences. The shaded entries indicate mainstream conferences that have hosted relevant themes. Entries above the thick line have been publicly announced and are forthcoming; those that are below the line have been held.

\begin{tabular}{|c|c|c|}
\hline 2001 & $\begin{array}{l}\text { May28 } \\
\text { June } 2\end{array}$ & $\begin{array}{l}\text { IFIP WG } 8.1 \text { Working Conference on Organisational Semiotics } \\
\text { Host: Montreal, Canada } \\
\text { Chair: Ronald Stamper }\end{array}$ \\
\hline 2000 & July 4 & $\begin{array}{l}3^{\text {rd }} \text { International Workshop on Organisational Semiotics } \\
\text { Host: Staffordshire University, UK } \\
\text { Committee: Kecheng Kiu, Peter Andersen, Rodney J. Clarke, Ronald Stamper }\end{array}$ \\
\hline 1999 & Oct 15 & $\begin{array}{l}\text { Organisational Engineering Workshop- Challenging the OER-paradigm } \\
\text { Host: Delft University of Technology, The Netherlands } \\
\text { Chair: Jan Dietz }\end{array}$ \\
\hline 1999 & Oct $12-14$ & 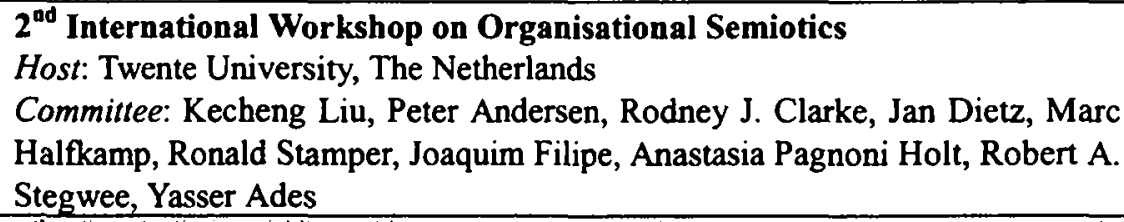 \\
\hline 1999 & Oct $3-6$, & 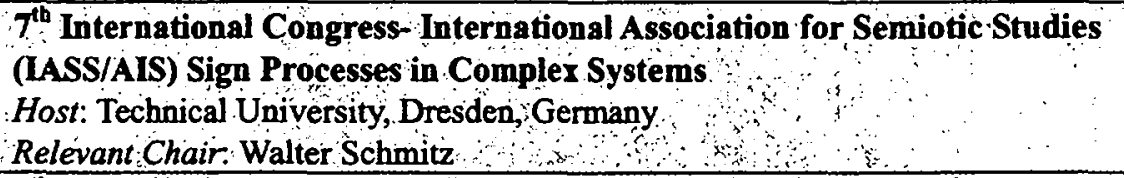 \\
\hline 1999: & Oct $3-6$ & $\begin{array}{l}9^{\text {th }} \text { International Congress of the German Society for Semiotic Studies } \\
\text { (DGS) Machines and History } \\
\text { Host: Technical University Dresden Germany } \\
\text { Relevant Chair. Walter Schmitz }\end{array}$ \\
\hline 1998 & Oct 13-15 & $\begin{array}{l}\text { Semiotics and the Information Sciences } \\
\text { Host: Victoria College, University of Toronto } \\
\text { Chairs: Jean Umiker-Sebeok, Marcel Denesi }\end{array}$ \\
\hline 1998 & Sept $14-17$ & $\begin{array}{l}\text { Intelligent Systems and Semiotics (ISAS) } \\
\text { Host: National Institute of Standards and Technology, Maryland USA } \\
\text { Relevant Chair: Alex M. Meystel }\end{array}$ \\
\hline 1997 & July $13-18$ & $\begin{array}{l}\text { 6 }^{\text {th }} \text { International Congress- International Association for Semiotic Studies } \\
\text { (IASS-AIS) Semiotics Bridging Nature and Culture } \\
\text { Host: Mexican Association for Semiotic Studies } \\
\text { Relevant Chair Adrián S. Gimate-Welsh }\end{array}$ \\
\hline 1997 & May 26-27 & 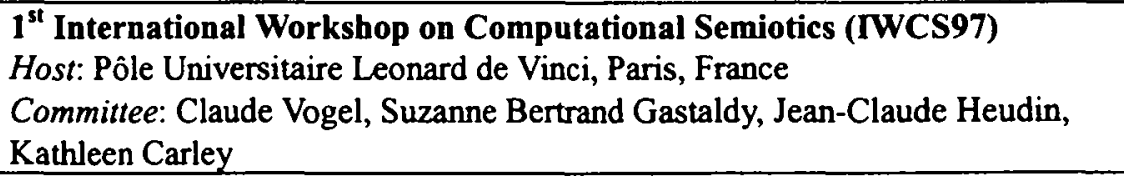 \\
\hline 1996 & Feb 19-23 & $\begin{array}{l}\text { Semiotics and Informatics Dagstuhl Seminar } \\
\text { Host: Schloss Dagstuhl- Inrenationales Begegnungs-und Forschungs-zentrum } \\
\text { für Informatik } \\
\text { Committee: Peter B. Andersen, Mihai Nadin, Frieder Nake }\end{array}$ \\
\hline 1995 & Feb $10-15$ & 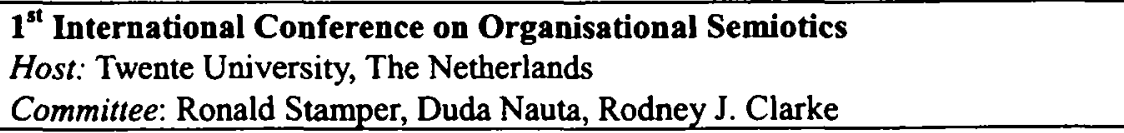 \\
\hline
\end{tabular}




\section{REFERENCES}

Andersen, P. B. (1990) A Theory of Computer Semiotics: Semiotic approaches to construction and assessment of computer systems Cambridge Series on Human-Computer Interaction Cambraidge: Cambridge University Press

Andersen, P. B. and T. Bratteteig eds/ (1989) Computers and Language at Work: The relevance of language and language use in development and use of computer systems Institute of Informatics, University of Oslo, Norway: Research Reports No 126

Andersen, P. B. and B. Holmqvist (1988) "Work language and information technology" in Andersen, P. B. and T. Bratteteig eds/ (1988) Computers and Language at Work: The relevance of language and language use in development and use of computer systems SYDPOL: System Development environments and Professional Oriented Languages, Institute of Informatics Research Reports No. 126, Institute of Informatics, University of Oslo, Norway, 117-155

Andersen, P. B.; Nadin, M. and F. Nake eds/ (1996) Informatics and Semiotics Dagstuhl-Seminar-Report 135; Schloss Dagstuhl- Internationales Begegnungs- Und Forschungszentrum für Informatik 9608, 19/02/9623/02/96

Bally, C.; Sechehaye, A. and A. Riedlinger eds/ (1993) F. de Saussure Course in General Linguistics (Cours de linguistique générale) Translated and annotated by Roy Harris UK: Duckworth

Chong, S. and K. Liu (2001) "A Semiotic Approach for Distinguishing Responsibilities in Agent-Based Systems" in Liu, K.; Clarke, R. J.; Andersen, P. B. and R. K. Stamper eds/ (2001) Information, Organisation and Technology: Studies in Organisational Semiotics Information and Organizational Design Series, Boston/Dordrecht/London: Kluwer Academic Publishers, Chapter 6, pp. 173-186

Clarke, R. J. (1995) "Genre in Systemic Functional Linguistics and the Analysis of Information Systems in Organisations" First International Conference on Organisational Semiotics February 10th-15th, University of Twente, The Netherlands

Clarke, R. J. (1996) "The Persistence of Systems in Organisations: Genre Analysis of Systems Decommissioning" in Holmqvist, B.; Andersen, P. B.; Klein, H. and R. Posner eds/ (1996) Signs of Work: Semiosis and Information Processing in Organisations Berlin: Walter de Gruyter, pp. 59-106

Clarke, R. J. (2000) "An Information System in its Organisational Contexts: A Systemic Semiotic Longitudinal Case Study" PhD Dissertation, Department of Information Systems, University of Wollongong

Clarke, R. J. (2001) "Towards a Systemic Semiotic Approach to Multimedia Interface Design" in Liu, K.; Clarke, R. J.; Andersen, P. B. and R. K. Stamper eds/ (2001) Information, Organisation and Technology: Studies in Organisational Semiotics Information and Organizational Design Series, Boston/Dordrecht/London: Kluwer Academic Publishers, Chapter 9, pp. 247-270

Döben-Henisch, G. (1998) "The Emergence of Signs in Populations of Artificial Agents" ISIC/CIRA/ISAS'98: IEEE International Symposium on Intelligent Control (ISIC), held jointly with International Symposium on Computational Intelligence in Robotics and Automation (CIRA) and Intelligent Systems and Semiotics (ISAS), National Institute of Standards and Technology, Gaithersburg, Maryland, USA, September 14-17, 1998, pp.

Dahlbom, B. ed/ (1993) Essays on Infology by Börge Langefors: Summing up and Planning for the Future Gothenburg Studies in Information Systems August 1993, Report 5, Department of Information Systems, Göteborg University, Sweden

Dahlbom, B. ed/ (1995) The Infological Equation: Essays in Honor of Börge Langefors Gothenburg Studies in Information Systems March 1995, Report 6, Department of Informatics, School of Economics and Commercial Law, Göteborg University, Sweden

de Souza, C. S. (1998) Personal Communication

Eco, U. (1976) A theory of Semiotics Bloomington: Indiana University Press

Falkenberg, et al eds/ (2000) Information System Concepts: an Integrated Discipline Emerging Boston, Dordrecht, London: Kluwer Academic Publishers

Fawcett, R. (1986) "Forward" in Ventola, E. (1987) The Structure of Social Interaction: A Systemic Approach to the Semiotics of Service Encounters Open Linguistics Series, London: Frances Pinter 
Fendt, K. E. (1999) "Non-Linear Coherence: Authorship, Readership, and the Social Construction of Knowledge in Hypermedia" in Machines and History (Machinen und Geschichte) Abstracts: $9^{\text {th }}$ International Congress of the German Society for Semiotic Studies (DGS), Technical University, Dresden, Germany, October 3-6, 1999, p.86

Fiol, C. M. (1989) "A Semiotic Analysis of Corporate Language: Organisational Boundaries and Joint Venturing" Administrative Science Quarterly Vol 34, pp. 277-303

Gudwin, R. R. and F. A. C. Gomide (1997) "An Approach to Computational Semiotics" Proceedings of the 1997 ISAS Conference, Gaithersburg, 1997, 467-470.

Gudwin (1999) "From Semiotics to Computational Semiotics" in Machines and History (Machinen und Geschichte) Abstracts: $9^{\text {th }}$ International Congress of the German Society for Semiotic Studies (DGS), Technical University, Dresden, Germany, October 3-6, 1999, p.77

Halliday, M. A. K. (1978) Language as social semiotic. The social interpretation of language and meaning Maryland, USA: Edward Amold

Halliday, M. A. K. (1985) An Introduction to Functional Grammar Melbourne: Edward Arnold

van Heusden, B. and R. Jorna (1999) "Knowledge Management and Innovation: On Sign Processes in Organisations" in Machines and History (Machinen und Geschichte) Abstracts: $9^{\text {th }}$ International Congress of the German Society for Semiotic Studies (DGS), Technical University, Dresden, Germany, October 3-6, 1999, p.22

Hjelmslev, L. (1943/1963) Prolegomena to a Theory of Language Menasha, Wisconsin: The University of Wisconsin Press

Hodge, R. and G. Kress (1988) Social Semiotics Cambridge, UK: Polity Press

Houser, N.; Eller, J. R.; De Tienne, A.; Lewis, A. C.; de Waal, C.; Bront Davis, D.; Cummins, L. and C. L. Clark eds/ (1999) Writings of Charles S.Peirce, A Chronological Edition, Volume 6 1886-1890 Peirce Edition Project, Indianapolis: Indiana University Press

Holmqvist, B. and P. B. Andersen (1987) "Work language and information technology" J. Pragmatics 11, 327 357

Kolkman, M. (1993) Problem Articulation Methodology PhD Thesis, Twente University, Enschede, The Netherlands

Köster, L. (1999) "Foundation of Semiotic Ergonomics" in Machines and History (Machinen und Geschichte) Abstracts: $\mathbf{9}^{\text {th }}$ International Congress of the German Society for Semiotic Studies (DGS), Technical University, Dresden, Germany, October 3-6, 1999, p.78

Kress, G. (1985) Linguistic processes in sociocultural practice ECS806 Sociocultural aspects of language and education, Victoria: Deakin University

Land, F. (1985) "Is an Information Theory Enough? The Computer Journal 28 (3) 211-215

Langefors, B. (1966) Theoretical Analysis of Information Systems Lund: Studentlitteratur

Liu, K. (1993) Semiotics Applied to Information Systems Development University of Twente, Enschede, The Netherlands

Liu, K. (2000) Semiotics in Information Systems Engineering Cambridge, UK: Cambridge University Press

Liu, K.; Clarke, R. J.; Andersen, P. B. and R. K. Stamper eds/ (2001) Information, Organisation and Technology: Studies in Organisational Semiotics Information and Organizational Design Series, Boston/Dordrecht/London: Kluwer Academic Publishers

Marcus, S. (1996) "Semiotically Relevant Aspects of Informatics" in Andersen, P. B.; Nadin, M. and F. Nake eds/ (1996) Informatics and Semiotics Schloss Dagstuhl, Internatuionales Begegnungs- und Forschungszentrum für Informatik, Dagstuhl-Seminar-Report 135, $19^{\text {th }}-23^{\text {rd }}$ February 1996

Marcus, S. (1999) "From Abstract Machines to Semiotic Machines and Back: A Semiotic Itinerary" in Machines and History. (Machinen und Geschichte) Abstracts: $9^{\text {tb }}$ International Congress of the German Society for Semiotic Studies (DGS), Technical University, Dresden, Germany, October 3-6, 1999, p.24

Martin, J. R. (1992) English Text: System and Structure Amsterdam: John Benjamins

Merkle, L. E. (1997) "Cognitive Signs, Human-Computer Interaction and Semiotics: Subliming Multifold Boundaries" Semiotics Bridging Nature and Culture- VIth International Congress, International Association for Semiotics Studies (IASS-AIS), Guadalajara, Mexico, July 13-18, 1997

Nadin, M. (1998) Personal Communication

Nilsson, A. G. (1995) Personal Communication

Nöth, W. (1990) Handbook of Semiotics Bloomington and Indianapolis: Indiana University Press

Pap, L. (1991) Semiotics: An Integrative Survey Toronto Semiotic Circle, Victoria College in the University of Toronto Monograph Series of the TSC, Number 7

Rieger, B. B. (1981) "Feasible Fuzzy Semantics: On some problems of how to handle word meaning empirically" in Eikmeyer, H. J. and H. Rieser eds/ (1981) Words, Worlds, and Contexts. New Approaches 
in Word Semantics Research in Text Theory 6, Berlin and New York: Walter de Gruyter, 193-209.

Rzevski, G. (1985) "On Criteria For Accessing An Information Theory" The Computer Journal 28 (3) 200-202

Schmidt, K-H. (1999) "A Semiotic View on Agents with Computable Perception" in Machines and History

(Machinen und Geschichte) Abstracts: $9^{\text {th }}$ International Congress of the German Society for Semiotic

Studies (DGS), Technical University, Dresden, Germany, October 3-6, 1999, p.78

Sless, D. (1986) In Search of Semiotics London and Sydney: Croom Helm

Stamper, R. (1973) Information in Business and Administrative Systems London: Batsford

Stamper, R. (2001) "Organisational Semiotics: Informatics without the computer" in Liu, K.; Clarke, R. J.; Andersen, P. B. and R. K. Stamper eds/ (2001) Information, Organisation and Technology: Studies in

Organisational Semiotics Information and Organizational Design Series, Boston/Dordrecht/London: Kluwer Academic Publishers, Chapter 5, pp. 115-171

Todorov, T. (1984) Mikhail Bakhtin: The Dialogical Principle Translated by Wlad Godzich, Theory and History of Literature (THL) Volume 13, Minneapolis: University of Minnesota Press

Tully, C. J. (1985) "Information, Human Activity and the Nature of Relevant Theories" The Computer Journal $28(3), 206-210$

Vogel, C.; Bertrand-Gastaldy, S. and J-C Heudin (1997) Statement for the 1st International Workshop on Computational Semiotics: 26th-27th May 1997 